\title{
Correction: 'Who contributes more?' How Ukrainian media construed migrants' life strategies vs. what the Ukrainian public wanted to know
}

\author{
Liudmyla Yuzva \& Anna Tashchenko (D)
}

Correction to: Humanities and Social Sciences Communications https://doi.org/10.1057/s41599-021-00978-5, published online 23 November 2021.

This article was published without the relevant funding information.

The online version of the paper and PDF has been corrected to include this information in the acknowledgements section.

This publication is financed by the Polish National Agency for Academic Exchange as part of the "International Academic Partnerships" under decision no. PPI/APM/2018/1/00019/DEC/1.

Published online: 06 December 2021

\footnotetext{
(c) (i) Open Access This article is licensed under a Creative Commons Attribution 4.0 International License, which permits use, sharing, adaptation, distribution and ceproduction in any medium or format, as long as you give appropriate credit to the original author(s) and the source, provide a link to the Creative Commons license, and indicate if changes were made. The images or other third party material in this article are included in the article's Creative Commons license, unless indicated otherwise in a credit line to the material. If material is not included in the article's Creative Commons license and your intended use is not permitted by statutory regulation or exceeds the permitted use, you will need to obtain permission directly from the copyright holder. To view a copy of this license, visit http://creativecommons.org/licenses/by/4.0/.
}

(C) The Author(s) 2021 